\title{
Rasulullah Sebagai Guru
}

\author{
Bahrum Subagiya \\ Email: bahrum.subagiya@uika-bogor.ac.id
}

Tanggal 25 November lalu bangsa ini merayakan hari guru. Hari guru ini diperingati bersamaan dengan ulang tahun Persatuan Guru Republik Indonesia (PGRI). Presiden Soeharto-lah yang menetapkan tanggal 25 November ini sebagai hari guru pada tahun 1994, (Keputusan Presiden, yaitu Kepres Nomor 78 tahun 1994 tentang Hari Guru Nasional) dan terus diperingati setiap tahunnya dalam bentuk upacara dan pemberian tanda jasa.

Bukan hanya di negara kita, hari guru pun diperingati juga oleh bangsa-bangsa lain. Negri jiran, Malaysia, memperingati hari guru di setiap tanggal 16 Mei. Singapura memperingati hari guru di setiap 1 September; Thailand memperingati di setiap di tanggal 16 Januari; Filipina dan Pakistan memperingati di setiap 5 Oktober; Amerika Serikat merayakan di Minggu pertama di bulan Mei (Minggu Apresiasi Guru) dan masih banyak negara lainnya memperingati juga hari guru di tanggal-tanggal yang berbeda.

Semua bangsa seakan sepakat bahwa guru merupakan orang yang sangat berjasa bagi bangsanya. Guru adalah tombak kemajuan suatu bangsa dan ia disebut sebagai seorang pahlawan tanpa tanda jasa. Guru memiliki peran penting dalam kehidupan berbangsa, tugas terbesarnya adalah mencerdaskan kehidupan bangsa. Karena dari gurulah lahirnya presiden, pejabat, ilmuan, dan orang-orang hebat.

Sebagai seorang muslim, tentu kita tidak melupakan sosok Rasulullah. Ia adalah seorang guru bagi umatnya. Tentunya pernyataan ini bukan omong kosong tanpa hujah. Allah menegaskan Rasulullah sebagai suri teladan yang baik, Al-Ahzab [33]: 21. Rasulullah sebagai teladan bukan hanya sebagai Rasul, dalam hal kepemimpinan, kepala rumah tangga, sebagai seorang ayah, sebagai seorang sahabat, sebagai pedagang, dan di segala model kehidupan beliau adalah contoh, termasuk contoh sebagai seorang guru.

Rasulullah adalah sosok seorang guru yang baik. Ia mengajar murid-murinya yang sekaligus beliau jadikan sebagai sahabat. Sehingga, hubungan seorang murid dengan gurunya begitu dekat. Ia mengajarkan bukan hanya dengan ucapan, tetapi jiwa, raga, tingkah laku dan perbuatannya menjadi pelajaran yang begitu berharga. Para muridnya menghafalkan, menjaga, dan mengamalkan apa yang diucapkan, dilakukan, dan ditetapkan oleh beliau. Pelajaran yang telah ditinggalkan Rasulullah kepada para sahabatnya merupakan hal yang sangat berharga. Generasi setelahnya terus merawat itu, hingga generasi berikutnya tiba, warisan itu tetap dijaga. Hingga saat ini, pelajaran yang diajarkan Rasulullah kepada para sahabatnya masih terjaga dalam kitab, Sahih Bukhari, Muslim, Sunan Abu Daud, Ibnu Majah, At-Tirmidzi, dan Musnad Imam Ahmad. 
Pelajaran yang diberikan Rasulullah akan terus terjaga hingga akhir hayat. Siapa saja yang mengambil pelajaran dari Rasulullah dan mengimplementasikan di dalam kehidupan ini, maka ia akan berjaya. Sebaliknya, siapa saja yang enggan dan tidak mau mengambil pelajaran dari Rasulullah, maka ia bisa celaka. 